\section{Kushnir M. Tokarieva $\mathbf{K}$.}

\title{
FINANCIAL TIME SERIES MODELLING: RETURN ON ASSETS
}

Робота присвячена дослідженню окремих аспектів часових рядів фінансових даних, зокрема моделюванню їх рентабельності. Об'єктом дослідження є система показників аналізу рентабельності фінансових часових рядів. Існує ключова особливість, яка відрізняє аналіз фінансових часових рядів від аналізу інших часових рядів, яка полягає в тому, що фінансова теорія та ї̈ емпіричні часові ряди містять елемент невизначеності. В результаті наявності чієї додаткової невизначеності статистична теорія та їі методи і моделі відіграють важливу роль у аналізі фінансових часових рядів.

Одним з найбільш проблемних місць є використання цін активів та їх волатильності у аналізі та прогнозуванні фінансових часових рядів, що є хибним, оскільки такі ряди містять елемент невизначеності. Тому в задачах такого типу повинна використовуватись так звана рентабельність фінансових активів та інструментів.

В роботі детально розглянуто типи рентабельності фінансових активів, які можуть бути використанні у математичному моделюванні та прогнозуванні фондових індексів. В ході дослідження використовувалися статистичні методи, що дозволили усунути недоліки використання цін фінансових активів в аналізі та прогнозуванні фінансових часових рядів. Розглянуто емпіричні властивості фінансових часових рядів на прикладі індексів ПФТС (Першої фондової торгової системи) та S \&्P 500.

Отримано комплексну систему показників аналізу часових рядів фінансових активів. Запропонована система передбачає використання численних методів розрахунку рентабельності (прибутковості) активів з метою визначення значимих статистичних характеристик даних. Завдяки побудованій системі показників забезпечується можливість здійснення емпіричного прогнозування часових рядів фінансових даних. У порівнянні із аналогічними відомими методами використання цін (а не рентабельності) на активи, це забезпечує ключову перевагу, яка дозволяє враховувати елементи невизначеності фінансовоекономічних даних.

Ключові слова: фінансові часові ряди, рентабельність активів, математичне моделювання фондових індексів.

\section{Introduction}

Today, financial markets are the defining element of the economic and social systems of modern society. In addition, financial activity plays an important role in the global economy, influencing the economic development of most countries of the world [1]. In financial markets, the success of an investor depends on the quality of the information that it uses to support decision-making, as well as how quickly it is able to make decisions. Therefore, due to its practical importance, the analysis of financial markets in recent decades has been widely studied by scientists in the field of mathematics, computer science and engineering [2].

Forecasting financial time series can be considered one of the main tasks in the scientific literature, the purpose of which is to study time series [3, 4]. Recall that a time series is a set of observations $x_{t}$, determined at time $t$, that is, it is a series of data points indexed in chronological order.

Analysis of financial time series follows from the theory and practice of valuing financial assets over time. Let's note that there is a key feature that distinguishes the analysis of financial time series from the analysis of other time series, which is that financial theory and its empirical time series contain an element of uncertainty.

For example, there are various definitions of asset volatility, but volatility is not directly observed for time series of stock returns. As a result of this additional uncertainty, statistical theory and its methods and models play an important role in the analysis of financial time series. Therefore, it is relevant to study the statistical characteristics of the profitability of financial assets and instruments.

Let's note that the publication [5] provides two main reasons for using profitability. The first one is that for most investors, profitability is the main assessment of investment opportunities, and the second is that profitability has more «attractive» statistical characteristics than asset prices. There are several definitions of the profitability of financial assets. Let's define them in detail.

So, the object of research is a system of indicators for analyzing the profitability of financial time series. And the aim of research is simulation of the main statistical characteristics of the profitability of the S\&P 500 and PFTS (First Stock Trading System) indices. 


\section{Methods of research}

The following scientific methods are used:

- system analysis method for identifying features of the time series of financial data;

- classification method in the study of types of interest accrual.

\section{Research results and discussion}

Let $P_{t}$ - the price of an asset at time $t$. Then it is possible to distinguish between the types of profitability $\left(R_{t}\right)$ of financial assets.

1. Single-period simple profitability. When determining the asset for one period $t-1$ from time $t-1$ to time $t$, let's obtain a simple gross margin:

$$
1+R_{t}=\frac{P_{t}}{P_{t-1}} \quad \text { or } \quad P_{t}=P_{t-1}\left(1+R_{t}\right)
$$

Accordingly, single-period simple net profitability have the form:

$$
R_{t}=\frac{P_{t}}{P_{t-1}}-1=\frac{P_{t}-P_{t-1}}{P_{t-1}} .
$$

2. Multi-period simple profitability. In determining the asset for $k$ periods between dates $t-k$ and $t$, let's obtain a $k$-period simple gross margin:

$$
\begin{aligned}
& 1+R_{t}[k]=\frac{P_{t}}{P_{t-k}}=\frac{P_{t}}{P_{t-1}} \cdot \frac{P_{t-1}}{P_{t-2}} \cdot \ldots \cdot \frac{P_{t-k+1}}{P_{t-k}}= \\
& =\left(1+R_{t}\right)\left(1+R_{t-1}\right) \ldots\left(1+R_{t-k-1}\right)=\prod_{j=0}^{k-1}\left(1+R_{t-j}\right) .
\end{aligned}
$$

The corresponding $k$-period simple net profitability to have the form:

$$
R_{t}[k]=\frac{\left(P_{t}-P_{t-k}\right)}{P_{t-k}} .
$$

In practice, the actual time interval is important for the analysis of profitability (for example, monthly or annual profitability) in order to make appropriate effective management decisions. If the time interval is not specified, then it is implicitly assumed to correspond to one year. If the asset is analyzed from $k$ years, then the calculation of profitability on an annual basis (average) will look like (it is also called annualized):

$$
\left\{R_{t}[k]\right\}=\left[\prod_{j=0}^{k-1}\left(1+R_{t-j}\right)\right]^{1 / k}-1 .
$$

It is obvious that this is the geometric mean $k$-period of simple gross margin and can be calculated as:

$$
\left\{R_{t}[k]\right\}=\exp \left[\frac{1}{k} \sum_{j=o}^{k-1} \ln \left(1+R_{t-j}\right)\right]-1,
$$

where $\exp (x)$ - the exponential function, and $\ln (x)-$ the natural logarithm of the positive values $x$. Since the arithmetic average is easier to calculate than the geometric, as well as single-period profitability is small, it is pos- sible to use the first-order Taylor series to approximate the canceled profitability:

$$
\left\{R_{t}[k]\right\} \approx \frac{1}{k} \sum_{j=0}^{k-1} R_{t-j}
$$

3. Profitability of the continuous accrual of compound interest (compounding or the logarithm of profitability, log-profitability) is expressed as:

$$
r_{t}=\ln \left(1+R_{t}\right)=\ln \frac{P_{t}}{P_{t-1}}=p_{t}-p_{t-1}
$$

where $p_{t}=\ln \left(P_{t}\right)$. The profitability of the continuous accrual of compound interest $r_{t}$ has certain advantages over simple net profitability $R_{t}$. So, let's consider multi-period profitability:

$$
\begin{aligned}
& r_{t}|k|=\ln \left(1+R_{t}|k|\right)=\ln \left[\left(1+R_{t}\right)\left(1+R_{t-1}\right) \ldots\left(1+R_{t-k+1}\right)\right]= \\
& =\ln \left(1+R_{t}\right)+\ln \left(1+R_{t-1}\right)+\ldots+\ln \left(1+R_{t-k+1}\right)= \\
& =r_{t}+r_{t-1}+\ldots+r_{t-k+1}=r_{t}+r_{t-1}+\ldots+r_{t-k+1} .
\end{aligned}
$$

Thus, the multi-period profitability of the continuous accrual of compound interest is the sum of the singleperiod profitability of the continuous accrual of compound interest. It should be noted that finding the statistical characteristics of the logarithms of profitability is simpler in the calculations.

4. Profitability of the investment portfolio. The simple net profitability of investment portfolio, consisting of $N$ assets, is the weighted average of the simple net return on assets, in which the weight of each asset is a percentage of the investment portfolio invested in this asset. Let $p$ denote the investment portfolio that has weight $w_{i}$ in the asset $i$. Then the simple profitability of the portfolio $p$ at time $t$ will be:

$$
R_{p, t}=\sum_{i=1}^{N} w_{i} R_{i t},
$$

where $R_{i t}$ - the simple profitability of the asset $i$.

5. Payment of dividends. If the asset involves the periodic payment of dividends, their profitability of such an asset must be modified. Let's denote by $D_{t}$ payment of dividends on the asset in the period from $t-1$ to $t$, and by $P_{t}$ the price of the asset at the end of period $P_{t}$, in this case, dividends are not included in $P_{t}$. Then the simple net profitability and the profitability of the continuous accrual of compound interest at time $t$ will have the corresponding form:

$$
R_{t}=\frac{P_{t}+D_{t}}{P_{t-1}}-1, r_{t}=\ln \left(P_{t}+D_{t}\right)-\ln \left(P_{t-1}\right) \text {. }
$$

6. Excess return (profitability) of an asset at time $t$ is expressed by the difference between the return on the asset and the return on some underlying asset. The simple net excess profitability and excess profitability of the continuous accrual of compound interest at time $t$ will have the corresponding form:

$$
Z_{t}=R_{t}-R_{0 t}, z_{t}=r_{t}-r_{0 t},
$$


where $R_{0 t}$ and $r_{0 t}$, respectively, is the simple profitability and the profitability of the continuous accrual of compound interest of the underlying asset.

It is obvious that the relationship between simple profitability $R_{t}$ and log-profitability $r_{t}$ is set through the ratio:

$$
r_{t}=\ln \left(1+R_{t}\right), R_{t}=e^{r_{t}}-1
$$

If profitability $R_{t}$ and $r_{t}$ is expressed as a percentage, then:

$$
r_{t}=100 \ln \left(1+\frac{R_{t}}{100}\right), R_{t}=100\left(e^{r_{t} / 100}-1\right) .
$$

The distribution of time series of financial assets (in this case, profitability) also has its own characteristics. The most common model of the logarithms of profitability $\left\{r_{i t} ; i=1, \ldots, N ; t=1, \ldots, T\right\}$ is the joint distribution function:

$$
F_{r}\left(r_{11}, \ldots, r_{N 1} ; r_{12}, \ldots, r_{N 2} ; \ldots ; r_{1 T}, \ldots, r_{N T} ; \mathbf{Y} ; \theta\right)
$$

where $\mathbf{Y}$ - the vector of variables describing the environment, profitability of assets, and $\theta$ - the vector of parameters of the distribution function.

The probability distribution $F_{r}(\cdot)$ determines the stochastic behavior of profitability $\left\{r_{i t}\right\}$ and $\mathbf{Y}$. In the financial literature [6, 7], the vector $\mathbf{Y}$ is interpreted as given, so an empirical analysis of return on assets consists in evaluating an unknown parameter $\theta$ and statistical behavior $\left\{r_{i t}\right\}$ for given historical data of profitability logarithms.

Some financial research sources focus on the joint distribution of $N$ profitability at one point in time $t$, i. e., distribution $\left\{r_{1 t}, \ldots, r_{N t}\right\}$. Also, one can find an emphasis on the dynamic structure of the profitability of individual assets, that is, the distribution $\left\{r_{i 1}, \ldots, r_{i T}\right\}$ for a given asset $i$. However, the joint distribution $\left\{r_{i t}\right\}_{t=1}^{T}$ for asset $i$ is most studied. In this case, transformations of the general distribution should be carried out as:

$$
\begin{aligned}
& F\left(r_{i 1}, \ldots, r_{i T} ; \theta\right)=F\left(r_{i 1}\right) F\left(r_{i 2} \mid r_{i 1}\right) \ldots F\left(r_{i T} \mid r_{i, T-1}, \ldots, r_{i 1}\right)= \\
& =F\left(r_{i 1}\right) \prod_{t=2}^{T} F\left(r_{i t} \mid r_{i, t-1}, \ldots, r_{i 1}\right),
\end{aligned}
$$

where, for the sake of simplicity, the parameter $\theta$ is omitted.

This separation emphasizes the temporal dependence of the logarithms of profitability $r_{i t}$. In this case, the main problem is the determination of the conditional distribution $F\left(r_{i t} \mid r_{i, t-1}\right)$, in particular, how it changes over time. In finance, different distribution characteristics lead to different hypotheses. For example, one of the versions of the hypothesis of random changes in asset prices is that conditional distribution $F\left(r_{i t} \mid r_{i, t-1}, \ldots, r_{i 1}\right)$ corresponds to a separate distribution $F\left(r_{i t}\right)$. In this case, the profitability is temporarily independent, and therefore unpredictable.

Let's note that the profitability of assets is also considered to be a continuous random variable (especially in the case of analysis of stock indices with a low periodicity, as in the case under consideration) and use the distribution density. In this case, from (10):

$$
F\left(r_{i 1}, \ldots, r_{i T} ; \theta\right)=F\left(r_{i 1} ; \theta\right) \prod_{t=2}^{T} F\left(r_{i t} \mid r_{i, t-1}, \ldots, r_{i 1} ; \theta\right) .
$$

From relation (11) it follows that conditional distribution is more appropriate than isolated when studying the profitability of financial assets. However, isolated distributions can still cause some interest, in particular, in this case it is easier to estimate the limit distributions than conditional distributions using historical time series. In addition, in some cases, the return on assets has weak empirical autocorrelation, and therefore, their marginal distributions are close to their conditional distributions.

In total, in the scientific literature [8] there are several statistical distributions of the profitability of financial assets, including normal distribution, log-normal distribution, stable distribution and the final mixture of normal distributions. Let's consider some of their features for use in the analysis of financial assets.

The traditional assumption in the scientific literature on finance $[7,8]$ is that simple profitability $\left\{R_{i t} \mid t=1, \ldots, T\right\}$ is independently equally distributed with a fixed mathematical expectation and variance. This assumption makes the statistical characteristics of profitability solvable, but, in turn, leads to certain difficulties. Firstly, the lower limit of simple profitability is 1 , while the normal distribution can take any value on the data axis, and therefore, there is no lower limit. Secondly, if $R_{i t}$ is normally distributed, then multi-period simple profitability $R_{i t}[k]$ is not normally distributed, since it is a product of one-period simple profitability. Thirdly, the assumption of a normal distribution is often not suitable in practice, since the empirical return on assets has a positive excess coefficient.

Another generally accepted assumption is that the logprofitability $r_{t}$ of an asset is independently and equally normally distributed with mathematical expectation $\mu$ and variance $\sigma^{2}$. Then simple profitability is independent identically distributed random variables with mathematical expectation and variance, given as:

$$
\begin{aligned}
& E\left(R_{t}\right)=\exp \left(\mu+\frac{\sigma^{2}}{2}\right)-1, \\
& \operatorname{Var}\left(R_{t}\right)=\exp \left(2 \mu+\sigma^{2}\right)\left[\exp \left(\sigma^{2}\right)-1\right] .
\end{aligned}
$$

Similarly, if to denote by $m_{1}$ and $m_{2}$, accordingly, the expectation and variance of simple profitability $R_{t}$, which is log-normally distributed, then for the corresponding logprofitability, have:

$$
\begin{aligned}
& E\left(r_{t}\right)=\ln \left[\frac{m_{1}+1}{\sqrt{1+m_{2} /\left(1+m_{1}\right)^{2}}}\right], \\
& \operatorname{Var}\left(r_{t}\right)=\ln \left[1+\frac{m_{2}}{\left(1+m_{1}\right)^{2}}\right] .
\end{aligned}
$$

However, the log-normal distribution also does not satisfy all the properties of historical time series of stock indices, in particular, their profitability has a positive value of the excess coefficient.

A stable distribution acts as a natural generalization of the normal, since it is stable when added, which corresponds to the profitability of the continuous accrual of compound interest $r_{t}$. However, stable distributions do not have finite 
variance, contrary to most financial theories. In addition, statistical modeling of stable distributions is challenging. An example of a stable distribution is the Cauchy distribution, which is symmetric about its median but has infinite variance.

Some studies [5, 6] use a finite mixture of normal distributions. An example of such a distribution might be:

$$
r_{t} \sim(1-X) N\left(\mu, \sigma_{1}^{2}\right)+X N\left(\mu, \sigma_{2}^{2}\right),
$$

where $X-$ a Bernoulli random variable $(P(X=1)=\alpha$ and $P(X=0)=1-\alpha$ with $0<\alpha<1)$.

Let's note that economic globalization and the development of web services have significantly accelerated the integration of global financial markets in recent years. The movement of prices in one market can easily and instantly spread to another market, financial markets have become more dependent on each other, so they need to be considered together to better understand the dynamic structure of global finance. So, knowing how markets are interconnected is of great importance in finance. Similarly, for an investor or financial institution that owns several assets, the dynamic relationships between asset returns play an important role in decision making. The analysis of this situation is carried out using models and methods of multivariate analysis of time series. Accordingly, in the financial literature $[9,10]$ there is the concept of multidimensional profitability.

Let's denote by $\mathbf{r}_{t}=\left(r_{1 t}, \ldots, r_{N t}\right)^{\prime}$ the log-profitability of $N$ assets at time $t$, and by $\left\{r_{t}\right\}_{t=1}^{T}$ the corresponding joint distribution, which can be specified similarly to (10). Profitability analysis in this case focuses on the specification of the conditional distribution function $F\left(\mathbf{r}_{t} \mid \mathbf{r}_{t-1}, \ldots, \mathbf{r}_{1}, \theta\right)$. The mathematical expectation vector and the covariance matrix of a random vector $\mathbf{X}=\left(X_{1}, \ldots, X_{p}\right)$ are defined as:

$$
\begin{aligned}
& E(\mathbf{X})=\mu_{x}=\left[E\left(X_{1}\right), \ldots, E\left(X_{p}\right)\right]^{\prime}, \\
& \operatorname{Cov}(\mathbf{X})=\Sigma_{x}=E\left[(\mathbf{X}-\mu)\left(\mathbf{X}-\mu_{x}\right)^{\prime}\right] .
\end{aligned}
$$

Let's also note that relation (10) can be used to obtain the likelihood function of log-profitability $\left\{r_{1}, \ldots, r_{T}\right\}$ of the respective assets. If conditional distribution $f\left(r_{t} \mid r_{t-1}, \ldots, r_{1}, \theta\right)$ is normal with mathematical expectation $\mu_{t}$ and variance $\sigma_{t}^{2}$,

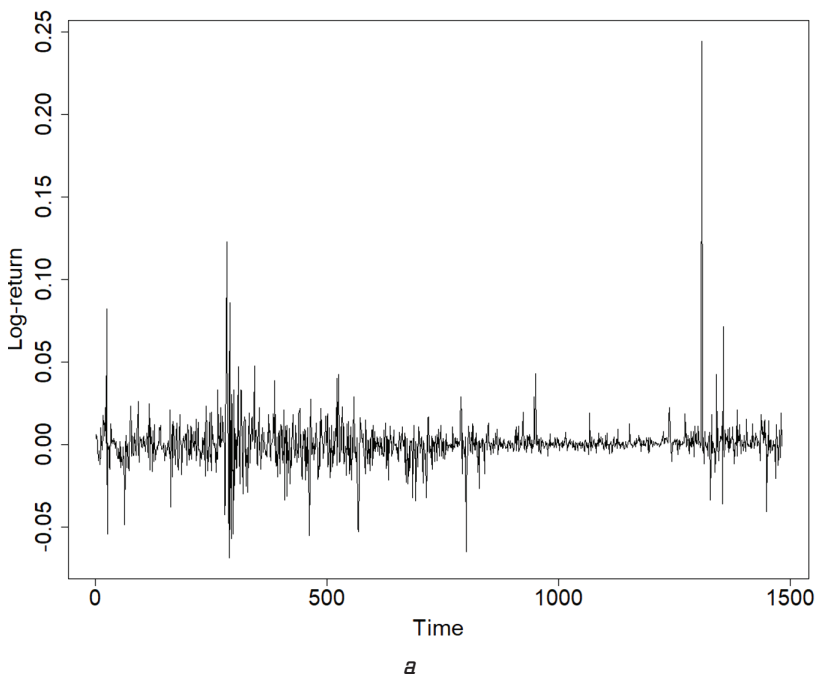

then $\theta$ consists of the parameters $\mu_{t}$ and $\sigma_{t}^{2}$, and the likelihood function has the form:

$$
f\left(r_{1}, \ldots, r_{T} ; \theta\right)=f\left(r_{1} ; \theta\right) \prod_{t=2}^{T} \frac{1}{\sqrt{2 \pi} \sigma_{t}} \exp \left[\frac{-\left(r_{t}-\mu_{t}\right)^{2}}{2 \sigma_{t}^{2}}\right]
$$

where $f\left(r_{1} ; \theta\right)$ - the distribution density of the first observation $r_{1}$. Value $\theta$, which is maximized this likelihood function, is an estimate of maximum likelihood $\theta$. Since the $\log$ function is monotonic, the maximum likelihood estimate can be obtained by maximizing the logarithmic likelihood function, which is easier to evaluate in practice:

$$
\begin{aligned}
& \ln f\left(r_{1}, \ldots, r_{T} ; \theta\right)= \\
& =\ln f\left(r_{1} ; \theta\right)-\frac{1}{2} \sum_{t=2}^{T}\left[\ln (2 \pi)+\ln \left(\sigma_{t}^{2}\right)+\frac{\left(r_{t}-\mu_{t}\right)^{2}}{\sigma_{t}^{2}}\right] .
\end{aligned}
$$

The logarithmic likelihood function can be obtained in a similar way if conditional distribution $f\left(r_{t} \mid r_{t-1}, \ldots, r_{1} ; \theta\right)$ is not normal. To guide the main statistical characteristics, time series of such stock indices were formed:

1. PFTS index for the period from 03.01.2013 to 09.01.2019. PFTS Exchange is one of the largest organizers of trading on the Ukrainian securities market; supports the interregional system of electronic trading in securities in real time. The PFTS Stock Exchange trading system has been operating since 1997 and technologically consists of a «quotes market», «orders market», REPO (from the English Repurchase agreement). The PFTS also holds auctions of the National Bank of Ukraine, auctions for the sale of securities by the State Property Fund of Ukraine, companies that conduct an initial public offering (IPO) of their own securities, or vice versa, sell their own assets in securities.

2. The S\&P 500 for the period from 07.05.2014 to 07.05.2019 a stock index, the basket of which includes 500 US joint stock companies with the largest capitalization. The list belongs to Standard\&Poor's and is compiled by it. It was first designed on March 4, 1957.

The corresponding graphs of the indicated time series are shown in Fig. 1. The corresponding statistical characteristics of the indices are given in Table 1.

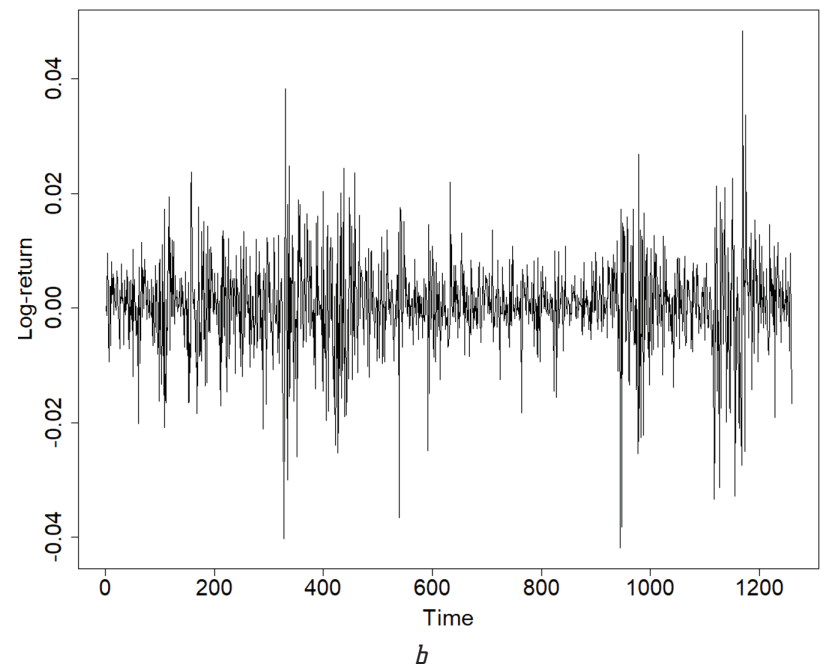

Fig. 1. Graphs of time series of profitability and logarithms of profitability of PFTS and $5 \& P 500$ indices: $a$ - log-profitability PFT5; $b$ - simple profitability S\&P 500 
Descriptive statistics of the simple and log-profitability of PFTS and S\&P 500 indices, \%

\begin{tabular}{|c|c|c|c|c|c|c|c|c|}
\hline Index & Number of observations & Average & Standard deviation & Minimum & Maximum & Asymmetry coefficient & Excess ratio \\
\hline \multicolumn{7}{|c|}{ Simple profitability, \% } \\
\hline PFT5 & 1481 & 0.0451 & 1.3690 & -6.6319 & 27.6746 & 6.3164 \\
\hline S\&P 500 & 1259 & 0.00375 & 0.83525 & -4.09792 & 4.95938 & -38.0616 & 387.1468 \\
\hline \multicolumn{7}{|c|}{ Log-profitability, \% } \\
\hline PFT5 & 1481 & 0.0362 & 1.3202 & -6.8620 & 24.4314 & 4.8664 \\
\hline S\&P 500 & 1259 & 0.0034 & 0.836444 & -4.18426 & 4.84032 & -45.219 & 38.2870 \\
\hline
\end{tabular}

The data in Table 1 allow the corresponding analysis of stock indices:

1) for indices, high values of excess coefficients are observed, that is, they have the property of minimal risk. With a decrease in the excess coefficient, the distribution of the random variable is smoothed, that is, the scattering of individual values of the economic indicator around the average value increases. This means that the uncertainty of obtaining a result grows and, accordingly, the risk increases;

2) the standard deviation of the $\mathrm{S} \& \mathrm{P} 500$ index is higher than in the PFTS;

3) on the whole, descriptive statistics show that the difference between simple profitability and log-profitability is not significant.

Fig. 2 shows the corresponding densities of the indices.

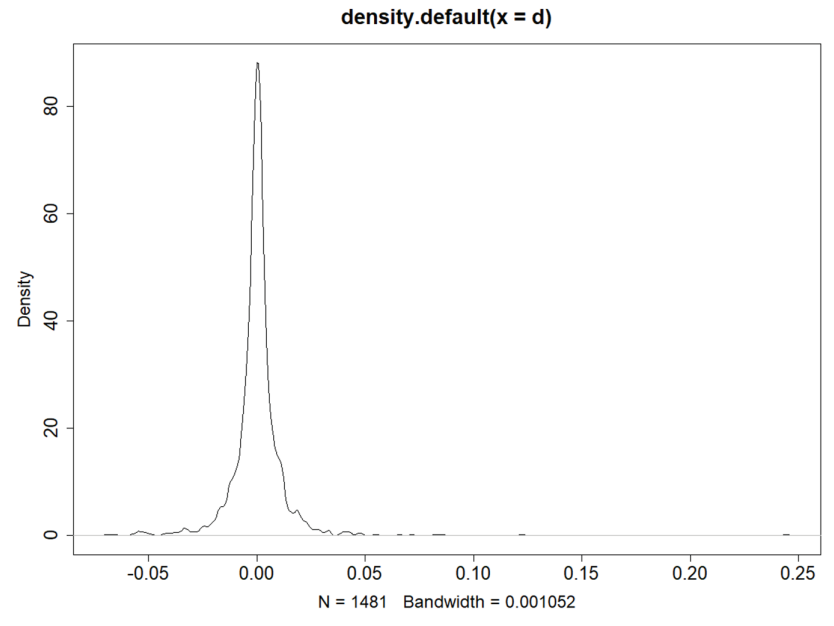

$a$

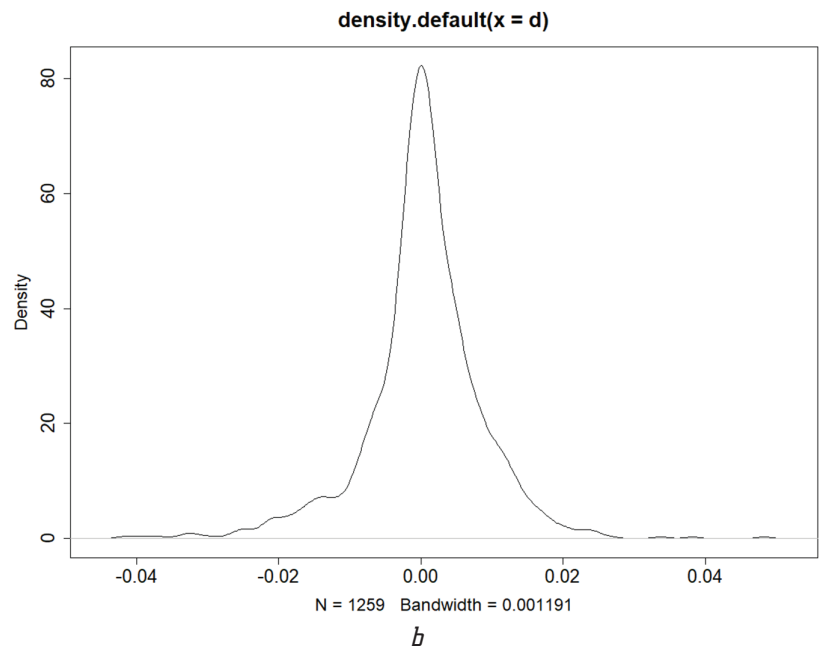

Fig. 2. The density of the indices: $a$ - PFTS log-profitability; $b$ - 5\&P 500 log-profitability
In Fig. 2 for comparison, empirical density and normal density are given (they coincide). The appearance of these functions confirms the assumption of a normal distribution of stock indices, as noted in the financial literature $[7,8]$, as mentioned above. The empirical density has, similarly, a higher peak and less gentle slopes, that is, it is higher and «narrow», which indicates some unaccounted factors and may be the subject of further scientific research.

\section{Conclusions}

Thus, the analysis of financial time series involves the use of numerous methods for calculating the profitability of assets in order to determine significant statistical characteristics of the data. A comprehensive system of indicators for analyzing the time series of financial assets has been obtained.

The proposed system provides for the use of numerous methods for calculating the profitability of assets in order to determine significant statistical characteristics of the data.

Thanks to the constructed system of indicators, it is possible to carry out empirical forecasting of time series of financial data. Compared to similar well-known methods of using prices (rather than profitability) for assets, this provides a key advantage that allows to take into account the elements of uncertainty of financial and economic data.

\section{References}

1. Lin, C.-S., Chiu, S.-H., Lin, T.-Y. (2012). Empirical mode decomposition-based least squares support vector regression for foreign exchange rate forecasting. Economic Modelling, 29 (6), 2583-2590. doi: http://doi.org/10.1016/j.econmod.2012.07.018

2. Yoo, P. D., Kim, M. H., Jan, T. (2005). Machine learning techniques and use of event information for stock market prediction: A survey and evaluation. Computational intelligence for modelling, control and automation and international conference on intelligent agents, web technologies and internet commerce, 835-841. doi: http://doi.org/10.1109/cimca.2005.1631572

3. Tay, F. E., Cao, L. (2001). Application of support vector machines in financial time series forecasting. Omega, 29 (4), 309-317. doi: http://doi.org/10.1016/s0305-0483(01)00026-3

4. Giacomini, R., Gottschling, A., Haefke, C., White, H. (2008). Mixtures of $\mathrm{t}$-distributions for finance and forecasting. Journal of Econometrics, 144 (1), 175-192. doi: http://doi.org/10.1016/ j.jeconom.2008.01.004

5. Campbell, J. Y., Lo, A. W., MacKinlay, A. C. (1997). The Econometrics of Financial Markets. Princeton: Princeton University Press. doi: http://doi.org/10.1515/9781400830213 
6. Kamaruzzaman, Z. A., Zaidi, I., Mohd Tahir, I. (2012). Mixtures of Normal Distributions: Application to Bursa Malaysia Stock Market Indices. World Applied Sciences Journal, 16, $781-790$.

7. Tsay, R. S. (2010). Analysis of Financial Time Series. Wiley. doi: http://doi.org/10.1002/9780470644560

8. Murphy, J. J. (1999). Technical analysis of the financial markets. New York: New York Institute of Finance, 542.

9. Lam, M. (2004). Neural network techniques for financial performance prediction: integrating fundamental and technical analysis. Decision Support Systems, 37 (4), 567-581. doi: http:// doi.org/10.1016/s0167-9236(03)00088-5
10. Vanstone, B., Finnie, G. (2010). Enhancing stockmarket trading performance with ANNs. Expert Systems with Applications, 37 (9), 6602-6610. doi: http://doi.org/10.1016/j.eswa.2010.02.124

Kushnir Mykola, PhD, Associate Professor, Department of Radio Engineering and Information Security, Yuriy Fedkovych Chernivtsi National University, Ukraine, e-mail: kushnirnick@gmail.com, ORCID: http:// orcid.org/0000-0001-9480-3856

Tokarieva Kateryna, Department of Radio Engineering and Information Security, Yuriy Fedkovych Chernivtsi National University, Ukraine,e-mail: tokarieva.chnu@gmail.com,ORCID:http://orcid.org/ 0000-0003-4007-8745 